\title{
EL MITO DE ORFEO Y LA MÚSICA EN LA VIDA DEL HOMBRE
}

\author{
Tomás Salazar Steiger \\ Universidad del Pacífico
}

Recibido: 14-11-2016

Aprobado: 18-02-2017

RESUMEN

Magíster en Teología y Filosofía por la Pontificia Universidad Católica de Chile. Allí también realiza actualmente sus estudios doctorales de Filosofía, en metafísica de la belleza. Es profesor de la Universidad del Pacífico en Lima, Perú desde el 2010, habiendo enseñado Filosofía, Teología, Ética y Apreciación Musical. $\mathrm{Ha}$ realizado actividades musicales como compositor, arreglista, director e intérprete.

salazar_te@up.edu.pe
La música acompaña al hombre en las experiencias principales de su vida: la fiesta, la muerte, la guerra, el amor, la religión. El poder de la música sido representado en el mito de Orfeo. Orfeo es el paradigma del músico genial: su música pone en trance a bestias salvajes y árboles, conmueve a ninfas y persuade a dioses. La música también ha sido objeto de reflexión de los filósofos griegos Pitágoras, Platón y Aristóteles, quienes la consideraban esencial en la vida del hombre. Estos pensadores de la Grecia antigua nos dan interesantes respuestas a la pregunta: ¿qué es la música?

Palabras clave: Orfeo, mito, música, filosofía, Grecia.

\begin{abstract}
Music accompanies man in his most significant experiences: celebration, death, war, love, religion. The power of music has been depicted in the myth of Orpheus. Orpheus is the paradigm of the musical genius: his music puts wild animals and trees into trances, it moves nymphs into tears and it persuades the gods. Music has also been an object of thought for the main Greek philosophers. Pythagoras, Plato and Aristotle thought it was essential for human life. Ancient Greek thinkers give us important contributions to answer the question: what is music?
\end{abstract}

Key words: Orpheus, myth, music, philosophy, Greece.

\section{LA MÚSICA}

¿Qué poder tiene la música en la vida del hombre? Este arte acompaña la historia del hombre desde los tiempos más primitivos. Y lo acompaña en las dimensiones y expresiones más diversas de su vida. Tenemos música sacra, como el canto gregoriano, pensada para unirse a Dios y expresar la paz espiritual de dicha unión. Tenemos Heavy Metal, con su iconografía satánica, violenta y destructiva. Hay música para ir a la guerra y música para el romance. Las diferencias históricas y culturales se perciben también en la música: el mismo fenómeno, el cortejo entre un hombre y una mujer, en el siglo XVIII se expresaba con un minueto, y hoy con el reggaetón. ¿Por qué nos fascina tanto la música? La intención de este trabajo es buscar algunas respuestas en la cultura griega, 
particularmente en el mito de Orfeo, y acompañarlas con la reflexión sobre la música en la filosofía de Pitágoras, Platón y Aristóteles. Este doble sendero (mito y filosofía) sigue la senda señalada por Aristóteles, cuando en su Metafísica, escribió: "Por eso también el que ama los mitos (philómythos) es en cierto modo filósofo (philósophós); pues el mito se compone de elementos maravillosos" (Aristóteles, Metafísica, I, 2).

La potencia de un mito suele verificarse en su vigencia: cuando capta bien el núcleo de un misterio, es recogido y transmitido por las generaciones. Es el caso del mito de Orfeo. Desde su composición en Grecia, este mito ha sido reseñado en prácticamente todas las épocas de la historia de Occidente. Entre las fuentes más importantes del mito están el libro cuarto de las Geórgicas de Virgilio, y los libros 15 y 18 de la Metamorfosis de Ovidio. En el medioevo temprano, los judíos le atribuyeron ser discípulo de Moisés en Egipto. Inspiró la interpretación alegórica-filosófica de Boecio, en La consolación de la filosofía. En la cristiandad medieval, se incorporó su figura y se desarrolló el OrfeoCristo: Orfeo como figura de Cristo, y su descenso al Hades en búsqueda de Eurídice representando la invitación de Cristo a la humanidad de entrar en su resurrección. Orfeo se hace presente también en la literatura de Quevedo, en Un Orfeo burlesco. El músico Monteverdi compuso La fábula de Orfeo, Offenbach escribió Orfeo en el inframundo, y Glück Orfeo y Eurídice. Haydn, Liszt y Stravinsky también han escrito música en relación a este mito. En las artes plásticas Durero y Rodin, tienen famosas obras dedicadas a Orfeo. En el siglo XX, Rilke escribe una obra maestra: Sonetos a Orfeo. En la música popular reciente, Orfeo ha inspirado la banda Orpheus, y a David Sylvian, Andrew Bird, y Arcade Fire. En cine, está el Orfeo de Jean Cocteau, o el Orfeo negro de Marcel Camus. Basten estos pocos ejemplos para sustentar la vigencia de este mito hasta el día de hoy.

Un dato adicional justifica nuestra investigación: nuestra palabra castellana, música, viene del griego musiké, "de las musas". La etimología nos remite a Grecia. Ir a los orígenes de la palabra y buscar el sentido de la música nos llevan al origen de la cultura occidental: Grecia, sus mitos y su filosofía. Orfeo fue engendrado por una musa y el número de cuerdas de su lira representa el número de las musas. 


\section{EL MITO DE ORFEO}

No existe una versión "original" completa del mito. No aparece en Homero ni Hesíodo. Diversos autores, desde íbico ( $\mathrm{VI} \mathrm{aC}$ ) en adelante, han presentado a Orfeo y han desarrollado aspectos de su historia, con diferencias en algunos casos importantes (por ejemplo, el éxito o fracaso en el rescate de Eurídice, o su muerte trágica o gloriosa). Sin embargo, a pesar de las diferencias, hay una columna vertebral común del mito que recogeremos acá.

Orfeo es hijo del rey tracio Eagro (aunque Píndaro lo presenta en un pasaje como hijo del dios Apolo), y Calíope, musa de la poesía épica y la elocuencia. Recibe de Apolo la lira, la cual él mismo perfecciona. La lira de Orfeo tiene nueve cuerdas, representando el número de las musas.

Simónides de Ceos $(+468 \mathrm{aC})$ es el primero en describir la peculiar relación que la música y el canto de Orfeo tienen con la naturaleza. Canta al aire libre, en cielo abierto, acompañándose con su lira. Desarrolla un arte completamente fuera de lo común: con su música es capaz de hacer que la naturaleza le obedezca: encanta a los pájaros, peces y animales salvajes, hace danzar a los árboles y piedras, e incluso cambia el curso de los ríos. La potencia de la música de Orfeo es tal, que plantas, animales salvajes y minerales alteran su comportamiento bajo su efecto.

Orfeo también fue argonauta. Simónides lo presenta a bordo de la nave Argo, y cuenta cómo sobre la cabeza de Orfeo había innumerables aves y los peces saltaban de las aguas encandilados por su dulce música. Apolonio de Rodas cuenta las aventuras de Orfeo en su Argonáutica: fue convocado por su maestría con la lira y, entre otros peligros, salvó a los marineros de las seductoras y mortales melodías de las sirenas, porque su música era aún más encantadora.

Orfeo se casa con Eurídice. Pero el día de su boda, un sátiro la intenta seducir, y mientas trata de huir, una serpiente la muerde fatalmente. Orfeo, al descubrir su cuerpo muerto, toca una música tan doliente que hace llorar a los dioses y las ninfas. Ellos lo persuaden de ir a rescatar a Eurídice del mundo de los muertos. Orfeo desciende al Hades a recuperarla, sorteando diversos peligros y venciéndolos todos con su 
música. Logra conmover también a Perséfone y Hades, y ellos dejan que Orfeo se lleve de vuelta a Eurídice. Orfeo logra lo imposible: obtener la revivificación de su amada. Una sola condición debe cumplir para este rescate: Orfeo no puede mirar hacia atrás durante el trayecto de retorno a la vida, hasta que la travesía haya terminado. Pero Orfeo desobedece la orden de no mirar atrás, y pierde a Eurídice. Esta parte del mito está desarrollada principalmente por los poetas romanos Ovidio y Virgilio. Su presencia en la Grecia antigua es escasa.

Orfeo, en el mundo de los vivos, ya no quiere saber de otra mujer que no sea Eurídice. Renunciando al trato femenino, es descuartizado por una banda de mujeres tracias. En esta etapa de su vida también es importante el elemento religioso. Se le presenta primero como sacerdote de Dionisio, dios de lo irracional, extático y orgiástico. Pero luego abandona ese culto para venerar a Apolo, dios de lo racional y armónico. Esta apostasía sería la causa de su muerte por las bacantes. La muerte de Orfeo tiene diferentes versiones. La versión recién reseñada proviene de un resumen que Eratóstenes realizó de una tragedia perdida de Esquilo $(+455 \mathrm{aC})$, Las Basárides. Ovidio, en cambio, señala que el desprecio del amor femenino, y el rechazo de muchas ninfas que se le ofrecieron, causó que las ménades, bacantes tracias seguidoras de Dionisio, lo descuartizaran en una orgía báquica. Según Pausanias (II dC), en cambio, existe una versión de que se suicidó por el dolor de no poder reunirse con Eurídice. En la versión de Diógenes Laercio (III dC) Zeus lo fulmina de un rayo por revelar los misterios divinos a los hombres.

La historia de sus restos también es significativa. Su cabeza y su lira, aún entonando música, flotan en el Hebro hasta llegar a la isla de Lesbos, donde Apolo les da poder profético. Otra versión relata que los habitantes de Lesbos recogieron sus restos del Hebro, enterraron su cabeza y construyeron un templo. Allí Orfeo profetizaba, hasta que Apolo lo silenció. En otro relato se cuenta que la lira fue llevada al cielo por las musas y ahora es una constelación. Los fragmentos de su cuerpo se enterraron bajo el monte Olimpo, y ahí cantan los ruiseñores. Hasta aquí el mito.

Distinguimos el efecto de la música de Orfeo en dos ámbitos: la naturaleza y los seres personales. Orfeo tiene una connaturalidad especial con el cosmos. Las representaciones visuales antiguas el mito muestran a la audiencia de Orfeo en trance, en escucha y dispuestos a la obediencia. Por un lado, el músico comprende el mensaje que está en 
la esencia de la naturaleza y es capaz de expresarlo: es capaz de desentrañar el lenguaje íntimo del mundo, de escuchar los sonidos que otros no perciben. Por eso le prestan atención: el músico habla su lenguaje. Orfeo canta el dolor y la belleza del mundo con una intensidad especial. Pero además, el músico también influye en la naturaleza: se presenta esta misteriosa respuesta del mundo natural al efecto que genera el artista. Orfeo es la representación mística del encantamiento, del poder mágico sobre la naturaleza. Por eso se relacionará a Orfeo con el mago o el chamán. Escuchando la raíz oculta, los misterios y paradojas del mundo, y expresándolos, puede también puede penetrar en su misterio e influirlo. Pero el poder de Orfeo sobre las estructuras de la naturaleza no es total. El fracaso de Orfeo en el rescate de Eurídice también lo pone en el contexto de los límites de su poder. El músico conoce y comprende de modo único el misterio de la realidad, y esa comprensión le da poder sobre ésta. Sin embargo, siendo un gran poder, es limitado.

Por otro lado, está el efecto que la música tiene en los seres personales: ninfas, dioses, personajes mitológicos y hombres. El efecto es más complejo, comprende los sentimientos y en la voluntad. Su canción más famosa en la tradición literaria, la que canta por Eurídice, es la canción del amor que quiere vencer a la muerte. Son los temas fuertes de la existencia humana. Y cuando Orfeo trata esos temas con su arte, hasta los dioses lo escuchan y se conmueven. Los mismos dioses creen que Orfeo puede vencer la muerte, y se dejan persuadir por él. Tal es la potencia de este instrumento expresivo, que puede persuadir al rey de la muerte que reviva a su amada. El amor escoge la música como el medio para lograr su pretensión de revivificación de la amada, de victoria sobre la muerte.

\section{MÚSICA EN LA FILOSOFÍA GRIEGA}

Aunque no existe registro de la música griega, hay abundante referencia en la literatura, filosofía, pintura y escultura griegas acerca de la música. En Grecia se prestó mucha atención a la música. Un hombre educado era llamado un hombre musical (aner mousikos), y uno inculto y burdo, amusical (aner amousos). En las prestigiosas competencias públicas de los agones, tras las pruebas gimnásticas venían los agones dionisíacos, con competencias musicales que tenían gran prestigio social: el vencedor era, como el atleta olímpico, héroe nacional, como Herodoto de Medara, trompetista, que ganó el premio olímpico 10 veces. En Esparta, Licurgo (aprox. VIlaC) legisló que hubiese educación 
musical regular y supervisada. Fomentó el uso del dorio, que promovía la virilidad, temperancia, sobriedad. En Atenas, Solón $(+558 a C)$ promovió la educación musical, exclusiva para los libres. En Arcadia la música era obligatoria hasta los 30 años. En Esparta, Tebas y Atenas todos tenían que tocar el aulos, y participar en un coro. $Y$ hay otras figuras mitológicas musicales aparte de Orfeo: el frigio Marsias, por ejemplo, un sátiro que confiado por tener la flauta de Atenas desafió a Apolo a un concurso. Cometió hybris al desafiar a un dios, y fue desollado vivo. En otro caso, Miseno desafió al dios marino Tritón a un concurso de trompeta, pero también perdió y fue ahogado.

En filosofía, son notables los descubrimientos y reflexiones de Pitágoras, Platón y Aristóteles.

Pitágoras $(+475 \mathrm{aC})$, matemático y filósofo, quedó fascinado por la estructura numérica de la realidad, y desarrolló una filosofía vinculada a las matemáticas, pensando que el número era el sustrato de la realidad, y que las esencias de las cosas eran numéricas. Respecto de la música, la contribución de Pitágoras es fundamental: descubrió y expresó la existencia de proporciones en los sonidos. Impresionado por el hecho de que los martillos de un herrero produjeran diferentes sonidos según su tamaño, diseñó el monocordio, y se dio cuenta de que la altura de un tono era inversamente proporcional al largo de la cuerda. Descubrió que la octava tiene proporción de 1:2 al tono fundamental, la quinta de 2:3, y así estableció las proporciones de los intervalos, y las relaciones entre estas proporciones y la consonancia y disonancia. La música está fundada en la física, la cual se funda en la matemática. Este descubrimiento permitió desarrollar la teoría de los armónicos, que es la base de la armonía, la escala musical, la jerarquía entre las notas, e incluso el timbre. Pitágoras vinculó este descubrimiento con su concepción del cosmos. Según su biógrafo Jámblico, «Pitágoras tendía su oído y fijaba su intelecto sobre los acordes celestes del universo. Él solo, por lo que parece, escuchaba y comprendía la armonía y el unísono universales de las esferas y de los astros» (Jámblico, Vida pitagórica, 65). Según Pitágoras, el universo es un inmenso instrumento musical que emite sonidos según las proporciones de su configuración esencial. Aristóteles expresa que los Pitagóricos «suponen que el firmamento entero es armonía y número» (Aristóteles, Metafísica, I, 5, 986a). De aquí surge la doctrina de la música de las esferas, que postula que las distancias entre las órbitas del sol, luna y estrellas fijas, corresponden a octava, quinta y cuarta. Los intervalos entre los cuerpos celestes se disponían de acuerdo a las leyes y relaciones de la armonía 
musical. El movimiento de los cuerpos celestes provocaban sonidos, incluso notas, dependiendo de sus distancias y velocidades.

Otro aspecto de la relación de Pitágoras con la música es el efecto terapéutico y pedagógico que le atribuía. Pitágoras comenzaba la educación por la música, «por medio de ciertas melodías y ritmos, gracias a los cuales sanaba los rasgos de carácter y las pasiones de los hombres, atraía la armonía entre las facultades del alma» (Jámblico, Vida pitagórica, 64; 29).

Platón $(+347 \mathrm{aC})$ reconoció la fundamental importancia de la música en la vida del hombre, particularmente en la educación. Según el historiador de la música Paul Henry Lang, Platón es el autor de la antigüedad que más profundamente discutió el rol ético y estético de la música (cf. Lang, 1969, p. 13). Hay referencias a la música en el Timeo, las Leyes, el Gorgias, el Filebo y La República. Platón no estudia la música como entretenimiento, sino desarrolla solamente su fundamental rol para la educación de la armonía y perfección del alma, y el orden de los sentimientos (pasiones). La música forma el carácter y la ética de la persona. Por eso, la música es un asunto público, no privado. Cada melodía, ritmo, e instrumento, tiene un efecto específico en la naturaleza moral del hombre y del estado. La buena música promueve el bienestar de la res pública y la mala música lo destruye.

Platón dedica una parte importante de La República a describir la formación de los gobernantes. Para Platón, la educación debe comenzar con la gimnasia y la música. La gimnasia para formar el cuerpo, y la música para formar el alma. Pero la música debe preceder y conducir la gimnasia, porque el cuerpo no ennoblece al alma, sino al revés. Gimnasia sin música lleva a la rudeza, música sin gimnasia a la melancolía y letargo. En la polis ideal de Platón, el Estado debe legislar la música, los modos y los instrumentos. Así comienza el texto sobre la educación de los guardianes:

\footnotetext{
-Adelante, pues, y, como si estuviéramos contando mitos, mientras tengamos tiempo para ello, eduquemos en teoría a nuestros hombres. -Hagámoslo.

- ¿Y qué clase de educación les daremos? ¿No será difícil hallar otra mejor que la que ha sido descubierta hace mucho tiempo, la gimnástica para el cuerpo y la música para el alma?

-Sera difícil, en efecto.

-Pues bien, ¿no comenzaremos por la música antes que por la gimnástica?

-Ciertamente (La República, II, 376e.).
} 
El Estado tendrá que velar por que haya músicos capacitados, para seguir «las huellas de la belleza y de la gracia». El contacto frecuente con la belleza de la música hará que los niños desde la tierna infancia desarrollen inconscientemente una afinidad, amistad y armonía con la belleza racional. Percibirán más agudamente las deficiencias y faltas de belleza, tanto en las obras de arte como en las naturales y repugnarán correctamente las cosas feas, y las odiarán, antes de alcanzar la razón de las cosas. "Conviene que la música termine en el amor de lo bello» (La República, III, 403c.), dice el filósofo. Platón plantea una interesante relación entre la belleza y la verdad, o entre el conocimiento estético y el racional. Y el conocimiento estético prepara el conocimiento racional. Así, cuando el joven llegue a la razón de las cosas, le dará la bienvenida, como a algo familiar. La educación musical es de suma importancia, dice Platón, porque "el ritmo y la armonía son lo que más penetra en el interior del alma y la afecta más vigorosamente, trayendo consigo la gracia, y crea gracia si la persona está debidamente educada, no sino lo está" (La República, III, 401c.).

Esta potencia nos hace pensar en Orfeo y su capacidad de conmover a dioses y ninfas, y hasta el mismo Hades. Otro pasaje de su obra en que queda clara la conciencia que Platón tenía de la influencia de la música en el ánimo del hombre era cuando en El Banquete (215b-c), Alcibíades compara la retórica de Sócrates con cuatro casos de influencia y persuasión. De estos cuatro, uno es Pericles y los otros tres son músicos. Alcibíades dice que Sócrates es como el sátiro Marsias, un hybristés ${ }^{1}$, que encanta a los hombres con su flauta, y hace que uno quede poseso. Sus melodías divinas revelan quién necesita de dioses y de ritos de iniciación. Los discursos de Sócrates son más seductores aún y también causan pasmo y posesión. Luego Alcibíades compara a Sócrates con los coribantes, grupo mítico de sacerdotes cuya música producía un trance místico de propiedades curativas en el que se decía oír la voz de la misma diosa Cibeles. Dice Alcibíades que, al escuchar a Sócrates, su corazón palpita mucho más que los poseídos por la música de los coribantes, y se conmueve hasta las lágrimas. Por último, Alcibíades compara la retórica de Sócrates con la música de las sirenas, cuyo poder de seducción atraía infaliblemente hacia las peñas en que se encontraba la muerte. Del mismo modo, los discursos de Sócrates hacen que la propia voluntad se destruya y uno termine a su lado.

\footnotetext{
${ }^{1}$ De difícil traducción: lujurioso, tramposo, embaucador, rompedor de reglas.
} 
Platón no solo habló de la influencia de la música de modo general, sino que hizo desarrollo de la relación entre los modos musicales particulares y las virtudes y vicios, y los estados de ánimo favorables o desfavorables. Las melodías en modos lidio mixto, lidio tenso, son quejumbrosas, y por lo tanto, deben ser suprimidas en la educación de los guardianes. Las melodías jonias y lidias son consideradas relajantes y se relacionan a la embriaguez, la molicie y la pereza. Por lo tanto, también deben ser suprimidas. Las únicas adecuadas para la educación de los guardianes son las dorias y frigias (Cf. La República, III, 398e399b.).

Para terminar de definir la íntima relación entre música y ética en Platón, vale la pena citar la definición de músico de Platón.

Pues bien, lo que afirmo ipor los dioses! es que no seremos músicos, ni nosotros ni aquellos de los que decimos deben ser educados, los guardianes, antes de que conozcamos las formas específicas de la moderación, de la valentía, de la liberalidad, de la magnanimidad y de cuantas virtudes se hermanan con ellas, así como de sus opuestas, en todas las combinaciones en que aparezcan por doquier, ni antes de que percibamos su presencia allí donde están presentes, ellas y sus imágenes, sin descuidarlas porque sean pequeñas o grandes, sino que pensaremos que una y otra cosa corresponden a un mismo arte y a un mismo estudio (La República, III, 402c.).

El músico es el que conoce el alma del hombre y sus múltiples estados anímicos y éticos, tanto como el que conoce sus imágenes musicales.

El rol ético-político de la música en Platón es enorme. Ella ocupa una posición muy elevada en la vida mental y espiritual de la nación. Se une a la visión de la ciudad como una comunidad moral, política y social, la creencia en el poder casi mágico y terapéutico de la música. La cualidad místico-religiosa de la música está intacta en Platón, pero él acentúa su dimensión ética, y relega la parte ritual al trasfondo.

El acento tan fuerte del rol ético de la música, hace que Platón tenga una lectura negativa del personaje de Orfeo. En el Banquete, Platón presenta a Orfeo como cobarde, por no querer morir por Eurídice. Su uso de la música es ilegítimo. Quiere engañar a los dioses, no entregarse por amor. Por esta cobardía lo despidieron del Hades sin nada: solo le mostraron el fantasma de su mujer. Además, como castigo adicional murió en manos de mujeres.

Aristóteles (+322 aC) reflexiona sobre la música en el capítulo dedicado a la educación en su obra Política. Primero considera su relación con el 
ocio: la música es parte del ocio de los hombres libres. Admite que la música puede ser juego, pues el juego tiene por fin el descanso, y el descanso tiene que ser agradable. También es diversión, pues la diversión tiene belleza y placer (y admite ambos elementos en la felicidad). La música pertenece a las cosas agradables. Pero en el Libro VIII, investiga si la música no será más valiosa que el mero entretenimiento. Aristóteles se pregunta si la música incita de alguna manera a la virtud, en lo que ella es capaz. Si es así, la música debe incluirse en la educación. ¿Contribuye la música a la formación del carácter y del alma? La respuesta es afirmativa: Aristóteles muestra con un ejemplo que es manifiesto que la música afecta nuestro carácter: la música produce entusiasmo, y el entusiasmo es una afección del carácter del alma.

Para continuar su análisis, Aristóteles define la virtud. Para él, la virtud consiste en gozar, amar y odiar de modo correcto. Por eso, lo que más debe aprenderse es a habituarse tanto como a juzgar con rectitud y gozarse en las buenas disposiciones morales y en las acciones honrosas. Según Aristóteles, «en los ritmos y en las melodías, se dan imitaciones muy perfectas de la verdadera naturaleza de la ira y de la mansedumbre y también de la fortaleza y de la templanza y de sus contrarios y de las demás disposiciones morales» (Política, VIII, 1340a). Y la evidencia de esto es que cambiamos de estado de ánimo cuando escuchamos estos acordes. Como Platón, Aristóteles también relaciona los modos con los estados de carácter: el mixolidio es más triste y grave, y los que se exponen a él sienten su mente más lánguida; el dorio se relaciona a un estado de ánimo intermedio y recogido; el frigio inspira el entusiasmo. Es interesante que entra en discusión con Platón respecto de los efectos concretos que cada modo tiene en el alma. Por ejemplo, piensa que Platón se equivoca al dejar subsistir el frigio con el dorio, porque el frigio también es orgiástico y pasional. $Y$ señala que algunos expertos en música censuran a Sócrates, por «haber rechazado los modos relajados en la educación por considerarlos embriagadores, no con los efectos de la embriaguez (pues la embriaguez produce más bien excitación báquica) sino como faltos de vigor» (Política, VIII, 1342b.).

Aristóteles señala que existe en nosotros una cierta afinidad con la armonía y el ritmo, y por eso hay sabios que afirman que el alma es armonía, o que tiene armonía. Dado que la música imprime cierta cualidad en el carácter del alma, es evidente que hay que educar musicalmente a los jóvenes. Y añade un criterio práctico de pedagogía: 
los jóvenes no soportan de buen grado nada falto de placer, y la música es por naturaleza placentera.

Aristóteles continúa la tradición platónica de vincular la flauta a lo orgiástico y la lira a lo racional. Por eso la flauta no sirve para la enseñanza, ni para el desarrollo de la inteligencia, pero sí para la purificación.

Por último, Aristóteles reconoce diferentes usos de la música: la educación, la purificación y la distracción. La educación es la dimensión racional, la purificación obedece a la orgiástica y la distracción para el relajamiento y descanso tras la tensión del trabajo.

\section{CONCLUSIÓN}

¿Qué es la música y cuál es su efecto en el corazón del hombre?, nos preguntábamos al inicio. El recurso al mito y a la filosofía nos ha dado unas respuestas.

La música es proporción. Podemos imaginar que cuando Pitágoras descubrió las proporciones de los intervalos, sintió que había revelado un enorme misterio de la naturaleza: en cierto sentido, había descubierto el lenguaje de la naturaleza: la proporción, los números, y había descubierto que la música es connatural a ese lenguaje. En ese sentido, Orfeo nos muestra la expresión del mismo hallazgo: el músico conoce el lenguaje íntimo del mundo, conoce sus misterios, y por eso es capaz de expresarlo. Pero el mundo también es afectado por su arte. Cuando por resonancia la nota de una soprano revienta una copa de cristal al hacer vibrar la copa en su frecuencia propia, es patente que la música tiene un poder transformador sobre la naturaleza misma. Por eso es que Orfeo no solo escucha y expresa, sino que la naturaleza le obedece. Quizás la imagen más hermosa de la imbricación entre naturaleza y música es el destino final de la lira de Orfeo: configurada como una constelación, su instrumento musical es naturaleza celestial.

Según Aristóteles, la música imita el alma. Y dado que el alma es o tiene armonía, el ritmo y la armonía musicales son lo que más vigorosamente afectan el alma, según señala Platón. Por eso, el músico genial, penetra con su música el corazón de su audiencia, y lleva a sus oyentes a experimentar sentimientos que ni ellos mismos quizás sabían que fueran posibles. Por eso el músico es un personaje fascinante y peligroso, a la vez amado y odiado. Su poder lo hace amigo y enemigo de los dioses. 
Marsias comete hybris y es castigado. Orfeo conmueve a ninfas y dioses. Pero las ménades lo descuartizan. Esta conmoción no solo afecta los sentimientos, sino también la voluntad. Es como la retórica de Sócrates: convence, seduce, lleva a la obediencia. Por eso es que Orfeo pudo convencer hasta el mismo Hades de obtener la revivificación de su amada.

Confirmamos en el mito y en la filosofía griega lo que intuíamos al inicio. Inmersos en el cosmos, absortos por los misterios de la naturaleza y del corazón humano, la música sigue siendo la compañera apropiada para expresarnos y conducirnos en las diferentes dimensiones de la nuestra existencia. El mito de Orfeo nos habla de este poder: los misterios más profundos: el amor, la muerte, el sentido de la vida individual, la relación con la trascendencia y con lo divino, el control o la sumisión ante la naturaleza, la vida social y la relaciones personales, escucha, entusiasmo, obediencia, la relación entre las dimensiones dionisíaca orgiástica y la apolínea racional de la vida humana, están todos en el núcleo de la actividad musical.

\section{BIBLIOGRAFÍA}

Aristóteles. (1988). Política. Madrid: Editorial Gredos.

Aristóteles. (1998). Metafísica. Madrid: Editorial Gredos.

Copleston, S.J., Frederick. (1993) A History of Philosophy. New York: Image Books.

Dodds. (1997). Los griegos y lo irracional. Madrid: Alianza Editorial.

Friedman, John. (1970) Orpheus in the Middle Ages. Massachusetts: Harvard University Press.

Jámblico. (1991). Vida pitagórica. Madrid: Editorial Etnos.

Lang, Paul Henry. (1969) History of music in Western Civilization. New York: Norton \& Company.

Maritain, Jacques. (1947) An Introduction to Philosophy. New York: Sheed \& Ward.

Platón. (2011) Diálogos I. Madrid: Editorial Gredos.

Platón. (2011) Diálogos II. Madrid: Editorial Gredos.

Segal, Charles. (1989) Orpheus. The myth of the poet. London: The John Hopkins University Press. 